\title{
Effect of particle size of naked oat flours on physicochemical and antioxidant property
}

\author{
Hyun-Il Jun ${ }^{1}$, Sun-Hee Yoo ${ }^{2}$, Geun-Seoup Song ${ }^{1}$, Young-Soo Kim ${ }^{1 *}$ \\ ${ }^{1}$ Department of Food Science and Technology, Chonbuk National University, Jeonju 54896, Korea \\ ${ }^{2}$ Agricultural Technology Center, Jeongeup 56141, Korea
}

\section{쌀귀리 가루의 입도별 이화학적 특성 및 항산화 활성}

\author{
전현일 ${ }^{1} \cdot$ 유선희 $^{2} \cdot$ 송근섭 ${ }^{1} \cdot$ 김영수 $^{1 *}$ \\ ${ }^{1}$ 전북대학교 식품공학과, ${ }^{2}$ 정읍시 농업기술센터
}

\begin{abstract}
This study was carried out to investigate the effect of particle size of naked oat flour (NOF) on physicochemical property and antioxidant activity. The NOF was passed through $250 \mu \mathrm{m}$ and $160 \mu \mathrm{m}$ size sieves to obtain three fractions (fraction A: $250 \mu \mathrm{m}$ or more, fraction B: $160-250 \mu \mathrm{m}$, and fraction C: $160 \mu \mathrm{m}$ or less). Moisture, crude protein, crude fat, and crude ash contents of NOF were 8.4, 15.7, 10.0, and $1.8 \%$, respectively, and these contents were increased as the particle size of NOF decreased. The mineral and free amino acid contents of NOF also had a similar tendency. The contents of total starch, amylose, starch damage, total dietary fiber, $\beta$-glucan, total phenolics, and flavonoids in NOF were 56.4\%, 21.4\%, 11.7\%, 11.0\%, 4.7\%, $237.8 \mathrm{\mu g} / \mathrm{g}$ and 90.9 $\mathrm{\mu g} / \mathrm{g}$, respectively. As the particle size of NOF decreased, total starch, amylose, and starch damage contents increased, whereas total dietary fiber, $\beta$-glucan, total phenolic and flavonoid contents decreased. Also, three antioxidant activities of NOF were closely correlated with their total phenolics and flavonoids contents, showing high correlation coefficient values $\left(R^{2}=0.87\right.$ and 0.81 , respectively).
\end{abstract}

Key words : naked oat flour, particle size, carbohydrate, physicochemical property, antioxidant property

\section{서 론}

벼과 작물인 귀리(Avena sativa L.)는 세계적으로 밀, 옥수 수, 벼, 보리 다음으로 많이 생산되고 있을 뿐만 아니라 양질의 단백질, 지질, 섬유질, 무기질, 페놀성 화합물 등을 함유하여 영양학적 가치가 높은 건강식품으로 인식되어 매년 소비량이 증가하고 있는 곡물이다(1,2). 품종별로는 껍질의 유무에 따라 겉귀리와 쌀귀리로 구분되며, 껍질 제 거가 용이한 쌀귀리가 영양성, 기호성 및 가공적성에서도 우수한 것으로 평가되고 있다 $(3,4)$. 과거에는 국산용 쌀귀

*Corresponding author. E-mail : ykim@jbnu.ac.kr Phone : 82-63-270-2569, Fax : 82-63-270-2572

Received 9 November 2017; Revised 22 November 2017; Accepted 23 November 2017.

Copyright (c) The Korean Society of Food Preservation. All rights reserved.
리 품종이 없어서 캐나다, 호주, 러시아 등에서 대부분 수입 하여 식용이나 가공제품에 사용하였으나 근래에는 국내에 서 재배 및 생산량이 적합한 조양, 선양, 대양 등과 같은 쌀귀리 품종이 개발되었다(5). 이 중에서 조양(Choyang)은 조숙성인 식용귀리를 모본으로 귀리 23호를 부본으로 교배 시켜 육종한 조숙성 품종으로 곡실의 발현율이 높고 수량이 많아 벼와 연계한 이모작 재배가 가능하여 국내산 쌀귀리의 국내 자급율 향상을 위해서 육성되었다(6).

국내 건강기능식품(2015년)의 시장규모는 전년대비 $16.2 \%$ 증가한 2 조 3,291 억 원이며, 그 중에서도 면역이나 항노화와 관련성이 높은 제품군이 $79.5 \%$ 이상으로 주를 이루고 있다(7). 이와 같은 건강기능식품 시장규모의 증가 는 체내에 과잉 생성된 활성산소종(reactive oxygen species, $\mathrm{ROS}$ ) 함량을 줄이거나 스트레스에 대한 면역시스템 증진 에 효과적인 식품소재와 이를 활용한 건강기능식품에 관심 이 높은 우리 사회의 상황이 반영된 결과로 판단된다 $(8,9)$. 
특히, 귀리에 다량 함유된 페놀성 화합물, $\beta$-glucan 등과 같은 생리활성 성분이 체내의 면역력을 증가시키고 노화를 지연시켜 고지혈증, 당뇨, 암 등의 만성질환 예방에 효과가 있다고 보고되어 건강에 관심이 많은 소비자들이 오트밀이 나 스낵 형태로 가공된 아침식사 용도로 이용하고 있으며, 그 수요가 증가하고 있다 $(10,11)$.

귀리를 이용한 가공제품을 개발하기 위해서는 제분하여 가루로 만드는 단계가 필수적이다(12). 귀리는 제분조건에 따라서 영양성분 함량 및 조성이 변화하는데, 그 중에서도 귀리에 가장 많이 존재하는 전분이 제분과정 중에 충격을 받아 손상되어 귀리의 가공적성에 영향을 주게 된다 $(13,14)$. 그러므로 곡류를 활용한 가공제품의 제조에는 입 도별 이화학적 특성 및 가공적성에 관한 정보가 필요하지만 이에 관한 연구가 아직까지는 미비한 실정이다. 이에 쌀귀 리의 활용도를 높이기 위한 기초자료를 얻고자 쌀귀리 가루 의 입도별 이화학적 특성 및 항산화 활성을 비교 분석하였다.

\section{재료 및 방법}

\section{실험재료 및 시약}

본 연구에 사용한 쌀귀리는 전북 정읍에서 생산된 조양 품종을 구입하여 수분함량이 $12 \%$ 까지 되도록 열풍건조하 였다. gallic acid, catechin, Folin-Ciocalteau reagent, butylated hydroxytoluene(BHT), 2,2-Diphenyl-1-picrylhydrazyl(DPPH), 2,2-azinobis(3-ethylenebenzothiozoline-6-sulfonic acid)(ABTS), glucose, maltose, fructose, rice starch 등은 Sigma-Aldrich사(St. Louis, MO, USA)에서 구입하였으며, 그 밖의 시약들은 analytical grade를 구입하여 사용하였다.

\section{쌀귀리의 제분 및 추출액 제조}

제분은 쌀귀리(control) $1 \mathrm{~kg}$ 을 roll 간격이 $0 \mathrm{~mm}$ 로 조절된 제분기(Single type stainless roller, Shinpoong Eng. Ltd., Gwangju, Korea)로 3회 분쇄하여 분말화하였다. 제분된 쌀 귀리 가루는 $250 \mu \mathrm{m}$ 와 $160 \mu \mathrm{m}$ 의 표준망체(Daihan Scientific Co., Ltd., Seoul, Korea)로 체질하여 $250 \mu \mathrm{m}$ 이상(fraction A), $160-250 \mu \mathrm{m}$ (fraction B) 및 $160 \mu \mathrm{m}$ 이하(fraction C)의 3 개의 군으로 분획하였다.

추출액은 시료 $2 \mathrm{~g}$ 에 $70 \%$ ethanol $20 \mathrm{~mL}$ 를 첨가하여 상온에서 3 시간 추출한 후에 원심분리 $(16,150 \times g, 10$ 분 $)$ 하 여 상등액을 얻는 과정을 3 회 반복하였다. 상등액은 여과 (Whatman No.4, GE Healthcare Bio-Sciences AB, Uppsala, Sweden)와 감압농축 $\left(40^{\circ} \mathrm{C}\right)$ 한 후 $10 \mathrm{~mL}$ 로 정용하여 항산화 활성의 분석시료로 사용하였다.

\section{일반성분 및 무기질 분석}

일반성분 함량은 $\mathrm{AOAC}(15)$ 방법을 이용하여 수분은 상
압가열건조법, 조회분은 직접회화법, 조지방은 Soxhlet법, 조단백은 Micro-Kjeldahl법으로 측정하였다.

무기질 함량은 식품공전 방법(16)으로 측정하였다. 시료 $0.5 \mathrm{~g}$ 에 증류수 $2 \mathrm{~mL}$ 와 nitric acid $8 \mathrm{~mL}$ 를 첨가하여 습식회 화한 후에 증류수를 첨가하여 $20 \mathrm{~mL}$ 로 정용한 용액을 분석 시료로 사용하였다. $\mathrm{K}, \mathrm{Ca}, \mathrm{Fe}, \mathrm{Na}, \mathrm{Mg}, \mathrm{Mn}, \mathrm{Zn}$ 및 $\mathrm{Cu}$ 는 ICP(iCAP6500, Thermo elemental Ltd., Cambridge, England) 로 분석하였으며, 분석조건은 RF power가 $1,150 \mathrm{~W}$, flush pump rate는 $50 \mathrm{rpm}$, nebulizer gas flow는 $0.5 \mathrm{~L} / \mathrm{min}$ 및 coolant gas flow는 $12 \mathrm{~L} / \mathrm{min}$ 이었다.

\section{유리아미노산 함량 분석}

유리아미노산 함량은 Spacknan 등(17)의 방법을 이용하 여 측정하였다. 시료 $1 \mathrm{~g}$ 에 $70 \%$ ethanol $30 \mathrm{~mL}$ 를 첨가하여 초음파 처리 $\left(30^{\circ} \mathrm{C}, 30\right.$ 분 $)$ 한 후에 원심분리 $(5,000 \mathrm{rpm}, 10$ 분 $)$ 하여 상등액을 얻는 과정을 3 회 반복하였다. 상등액은 감압 여과한 후에 $40^{\circ} \mathrm{C}$ 에서 감압농축하여 $70 \%$ ethanol을 완전히 제거하였다. 이 건조물에 $0.2 \mathrm{M}$ lithium citrate $\operatorname{buffer}(\mathrm{pH}$ 2.2) 용액을 첨가하여 $5 \mathrm{~mL}$ 로 정용한 후에 $0.22 \mu \mathrm{m}$ membrane filter(Chrom Tech, Inc., Apple Valley, MN, USA) 로 여과하여 Automatic amino acid analyzer(S4300, Sykam Co., Eresing, Germany)로 측정하였다. 분석조건은 column 은 lithium filter $(4.6 \times 100 \mathrm{~mm})$ 가 부착된 cation separation lithium $(4.6 \times 150 \mathrm{~mm})$, detector는 UV-Vis(440 nm-570 nm), buffer 유속은 $0.45 \mathrm{~mL} / \mathrm{min}$, ninhydrin 유속은 $0.25 \mathrm{~mL} / \mathrm{min}$, injection volume은 $100 \mu \mathrm{L}$ 이었다. Buffer의 조성은 $\mathrm{A}(\mathrm{pH}$ 2.85 , lithium citrate $1.41 \%+$ citric acid $0.7 \%$ +methanol $5 \%+\mathrm{HCl} 0.9 \%)+\mathrm{B}(\mathrm{pH} 4.20$, lithium cirtate $1.41 \%+$ citric acid $0.7 \%+\mathrm{HCl} 0.6 \%)+\mathrm{C}(\mathrm{pH} 3.30$, lithium citrate $1.88 \%+$ lithium chloride $5.07 \%+\mathrm{HCl} 1 \%$ )이었다.

\section{탄수화물 분석}

총 전분(total starch) 함량은 Megazyme total starch assay kit(Megazyme Pty., Ltd., Wicklow, Ireland)를 이용하여 McCleary 등(18)의 방법으로 측정하였다.

아밀로스 함량은 Williams 등(19)의 방법을 응용하여 측 정하였다. 시료 $400 \mathrm{mg}$ 을 $0.5 \mathrm{~N} \mathrm{KOH}$ 용액 $10 \mathrm{~mL}$ 에 분산시 킨 후에 증류수를 첨가하여 $100 \mathrm{~mL}$ 로 정용하였다. 희석용 액 $10 \mathrm{~mL}$ 에 $0.1 \mathrm{~N} \mathrm{HCl} 5 \mathrm{~mL}$, iodine 용액 $0.5 \mathrm{~mL}$ 및 증류수를 첨가하여 $50 \mathrm{~mL}$ 로 정용하였다. 실온에서 20 분 동안 방치한 후 $680 \mathrm{~nm}(\mathrm{UV}-1650 \mathrm{PC}$, Shimadzu Co., Kyoto, Japan)에서 흡광도를 측정하였으며, 표준물질은 rice starch를 사용하였 다.

손상전분(damaged starch) 함량은 Boyaci 등(20)의 방법 을 이용하였다. 시료 $9 \mathrm{~g}$ 에 a-amylase 용액 $(277.8 \mathrm{U} / \mathrm{mL})$ $45 \mathrm{~mL}$ 를 첨가한 후에 $30^{\circ} \mathrm{C}$ 의 수욕조에서 25 분간 반응시켰 다. 이 반응액에 $3.68 \mathrm{~N} \mathrm{H}_{2} \mathrm{SO}_{4} 3 \mathrm{~mL}$ 와 $12 \%$ sodium tungstate 
$2 \mathrm{~mL}$ 를 첨가하여 2분간 정치시킨 후에 여과(Whatman No.4)하였다. 굴절당도계(PAL-1, Atago Co., Ltd., Tokyo, Japan)로 여액의 ${ }^{\circ} \mathrm{Brix}$ 를 측정하여 전분손상도를 산출한 후에 이를 총 전분의 함량에 대입하여 손상전분 함량을 재산출하였다.

$$
\begin{aligned}
& \text { Degree of damaged } \operatorname{starch}(\%)=\frac{\left(\mathrm{B}_{2}-\mathrm{B}_{1}\right) \times \mathrm{V}}{\mathrm{M}} \times \mathrm{F} \\
& \mathrm{B}_{1} \text { : 효소가 첨가되지 않은 여액의 }{ }^{\circ} \mathrm{Brix} \\
& \mathrm{B}_{2} \text { : 효소가 첨가된 시료 여액의 }{ }^{\circ} \mathrm{Brix} \\
& \mathrm{M} \text { : 시료 무게 }(\mathrm{g}) \\
& \mathrm{V} \text { : 용액의 부피 }(50 \mathrm{~mL}) \\
& \mathrm{F} \text { : 변환 상수 }(1.64)
\end{aligned}
$$

총 식이섬유(total dietary fiber) 함량은 식이섬유 분석용 kit(TDF 100A, Sigma Chemical Co., St, Louis, Mo, USA)를 사용하여 Prosky 등(21)의 방법으로 측정하였다.

$\beta$-Glucan 함량은 Megazyme $\beta$-glucan assay kit(Megazyme Pty., Ltd.)를 이용하여 McCleary와 Glennie-Holmes(22)의 방법으로 측정하였다.

유리당 함량(free sugar)은 Cho 등(23)의 방법으로 측정하 였다. 시료 $1 \mathrm{~g}$ 에 $70 \%$ methanol $10 \mathrm{~mL}$ 을 첨가하여 microwaving extractor(MARS Xtraction, CEM Co., NC, USA)를 사용하여 $80^{\circ} \mathrm{C}$ 에서 60 분간 추출한 후에 원심분리 $(10,767 \times g, 10$ 분 $)$ 하 여 상등액을 얻는 과정을 3 회 반복하였다. 상등액은 감압여 과한 후에 $30 \mathrm{~mL}$ 로 정용하였으며, 이를 $0.22 \mu \mathrm{m}$ membrane filter로 여과하여 HPLC system(NS-2004GP, Futecs Co., Daejeon, Korea)으로 측정하였다. 분석조건은 column은 Asahipak NH2P-504E column $(4.6 \times 250 \mathrm{~mm}$, Showa Denko Co., Kanagawa, Japan), detector는 ELSD detector(Model 2000, Softa Co., Brighton, CO, USA), mobile phase는 acetonitrile:water=75:25 (v/v), flow rate는 $1.0 \mathrm{~L} / \mathrm{min}$, column oven의 온도는 $35^{\circ} \mathrm{C}$, injection volume은 $100 \mu \mathrm{L}$ 이었다. $\mathrm{HPLC}$ 에 의해서 분리된 각 유리당의 함량은 동일조건에서 분석한 표줄물질의 peak 면적의 비율과 retention time을 비교하여 분석하였으며 표준물질로는 glucose, maltose 및 fructose를 사용하였다.

\section{지방산 조성 분석}

지방산 조성은 Metcalfe 등(24)의 방법을 이용하여 지질 을 methyl ester화 시킨 후에 측정하였다. 시료 $10 \mathrm{~g}$ 에 diethyl ether $100 \mathrm{~mL}$ 를 첨가하여 soxhlet 추출법으로 약 10 시간 동안 추출한 후에 소량의 증류수를 첨가하고 분액 깔대기로 diethyl ether 층을 분리하였다. 분리된 diethyl ether 용액에 무수 $\mathrm{Na}_{2} \mathrm{SO}_{4}$ 을 첨가하여 탈수한 후에 여과지로 여과하였 다. 이 여과액을 $40^{\circ} \mathrm{C}$ 에서 감압농축하여 diethyl ether를 제 거한 지질을 지방산 분석시료로 사용하였다. 추출한 지질
$0.2 \mathrm{~g}$ 에 $0.5 \mathrm{~N} \mathrm{NaOH} /$ methanol $5 \mathrm{~mL}$ 를 넣고 10분간 수욕상에 서 가수분해시켰다. 여기에 $14 \% \mathrm{BF}_{3}$-methanol $5 \mathrm{~mL}$ 를 첨가 하고 2 분간 가열하여 methyl ester화한 후, n-hexane으로 추 출한 지방산 분석시료를 gas chromatography system $(\mathrm{GC}$, 6890N, Agilent Technologies, Santa Clara, CA, USA)으로 측정하였다. column은 $100 \mathrm{~m} \times 0.25 \mathrm{~mm}$ I.D.(film thickness $0.20 \mu \mathrm{m})$ 의 SP-2560 capillary column(Supelco, Inc., Bellefonte, PA, USA), detector는 FID, carrier gas는 $\mathrm{N}_{2}$, flow rate는 $1 \mathrm{~mL} / \mathrm{min}$, injection volume은 $10 \mu \mathrm{L}$ 이었다. Column 의 초기온도는 $140^{\circ} \mathrm{C}$ 이었고 5 분간 유지한 다음 $4{ }^{\circ} \mathrm{C} / \mathrm{min}$ 로 $240^{\circ} \mathrm{C}$ 까지 온도를 상승시켜 22 분간 유지하였으며 column 의 injector와 detector의 온도는 $260^{\circ} \mathrm{C}$ 이었다. $\mathrm{GC}$ 에 의해서 분리된 각 지방산 methyl ester를 peak 면적비로 계산하여 각 지방산의 조성비를 구하였다. 각 지방산 peak 면적은 동일조건에서 분석한 표준지방산 methyl ester mixture (supelco 37 comp FAME Mix $10 \mathrm{mg} / \mathrm{mL}$ in $\mathrm{CH}_{2} \mathrm{Cl}_{2}$ )와 retention time을 비교하여 분석하였다.

\section{물리적 특성 분석}

색도는 색차계(SP-80, Tokyo Denshoku, Tokyo, Japan)를 이용하여 귀리 가루의 $\mathrm{L}$ (명도), $\mathrm{a}$ (적색도), $\mathrm{b}$ (황색도)값을 측정하였다.

호화특성은 시료 $3.5 \mathrm{~g}$ 에 증류수 $25 \mathrm{~mL}$ 를 첨가하고 잘 혼합하여 RVA(RVA-4, Newport Scientific Pty., Ltd., Warriewood, Australia)로 측정하였다. 측정 중에 온도는 0-1.0분에서 $50^{\circ} \mathrm{C}$ 유지, $1.0-4.8$ 분에서 $95^{\circ} \mathrm{C}$ 까지 가열, 4.8-7.3분에서 $95^{\circ} \mathrm{C}$ 유지, 7.3-11.01분에서 $50^{\circ} \mathrm{C}$ 까지 냉각 및 11.01-12.05분에서 $50^{\circ} \mathrm{C}$ 를 유지하였다. 호화특성은 최고 점도, 최저점도, 최종점도, 강하점도 및 치반점도로 나타내 었다. 강하점도는 최고점도에서 최저점도를 뺀 값으로, 치 반점도는 최종점도에서 최저점도를 뺀 값으로 하였다.

\section{항산화 성분 및 항산화 활성 분석}

Total phenolic 함량(total phenolic content, TPC)은 Dewanto 등(25)의 방법을 이용하였다. 추출물 $0.1 \mathrm{~mL}$ 에 Folin-ciocalteu's phenol reagent $5 \mathrm{~mL}$ 를 첨가하여 1분간 반 응시킨 후에 $5 \% \mathrm{Na}_{2} \mathrm{CO}_{3} 3 \mathrm{~mL}$ 를 첨가하였다. 암소에서 1시간 동안 반응시켜 $765 \mathrm{~nm}(\mathrm{UV}-1650 \mathrm{PC}$, Shimadzu Co., Kyoto, Japan)에서 흡광도를 측정하였으며, 표준물질로는 gallic acid를 사용하였다.

Total flavonoid 함량(total flavonoid content, TFC)은 Jia 등(26)의 방법을 이용하였다. 추출물 $500 \mu \mathrm{L}$ 에 $5 \% \mathrm{NaNO}_{2}$ $75 \mu \mathrm{L}$ 을 첨가하여 5 분간 반응시킨 후에 $10 \% \mathrm{AlCl}_{3} 150$ $\mu \mathrm{L}$ 을 첨가하였다. $1 \mathrm{M} \mathrm{NaOH} 0.5 \mathrm{~mL}$ 와 증류수 $275 \mu \mathrm{L}$ 를 첨가하여 $510 \mathrm{~nm}$ 에서 흡광도를 측정하였으며, 표준물질로 는 catechin을 사용하였다.

DPPH radical assay는 Williams 등(27)의 방법을 변형하 
여 측정하였다. 시료 $100 \mu \mathrm{L}$ 에 $100 \mu \mathrm{M} \mathrm{DPPH}$ 용액 $2 \mathrm{~mL}$ 를 첨가하여 암소에서 20 분간 반응시킨 후에 $515 \mathrm{~nm}$ 에서 흡광 도를 측정하였으며, DPPH radical 소거능은 다음의 식으로 산출하여 나타내었다.

$$
\begin{aligned}
& \text { DPPH radical scavenging activity }(\%)= \\
& \frac{\text { absorbance of control-absorbance of sample }}{\text { absorbance of control }} \times 100
\end{aligned}
$$

ABTS radical assay는 Arts 등(28)의 방법을 이용하여 측 정하였다. 시료 $30 \mu \mathrm{L}$ 에 ABTS radical 용액 $3 \mathrm{~mL}$ 를 첨가하 여 암소에서 6 분간 반응시킨 후에 $734 \mathrm{~nm}$ 에서 흡광도를 측정하였으며, ABTS radical 소거능은 다음의 식으로 산출 하여 나타내었다.

ABTS radical cation scavenging activity $(\%)=$ $\frac{\text { absorbance of control-absorbance of sample }}{\text { absorbance of control }} \times 100$

Reducing power는 Oyaizu(29)의 방법을 이용하였다. 시 료 $1 \mathrm{~mL}$ 에 $0.2 \mathrm{M}$ phosphate buffer $(\mathrm{pH}$ 6.6) $2.5 \mathrm{~mL}$ 와 $1 \%$ $\mathrm{K}_{3} \mathrm{Fe}(\mathrm{CN})_{6} 2.5 \mathrm{~mL}$ 를 첨가하여 $50^{\circ} \mathrm{C}$ 에서 20 분간 반응시켰 다. 이 반응액에 $10 \%$ trichloroacetic acid $2.5 \mathrm{~mL}$ 를 첨가하여 원심분리 $(6,460 \times g, 10$ 분 $)$ 한 후에 상등액을 취하였다. 이 상등액 $5 \mathrm{~mL}$ 에 증류수 $5 \mathrm{~mL}$ 와 $0.1 \% \mathrm{FeCl}_{3} 1 \mathrm{~mL}$ 를 첨가하여 $700 \mathrm{~nm}$ 에서 흡광도를 측정하였으며, 대조구로는 ascorbic acid를 사용하였다. Reducing power는 시료액 첨가구와 무 첨가구의 흡광도 차이로 나타내었다.

\section{통계 분석}

각 실험은 3 회 반복 실험하여 얻은 결과를 SAS 통계 프로그램(SAS Institute, Cary, NC, USA)을 이용하여 평균 과 표준편차로 나타내었다(30). 각 시료간의 유의성은 $\mathrm{p}<0.05$ 수준에서 one way ANOVA로 분산분석한 후에 Duncan's multiple range test로 비교하였으며, 쌀귀리의 항 산화 성분과 항산화 활성의 연관성은 Pearson 상관분석을 이용한 단순회귀분석(simple regression analysis)을 실시하 여 비교하였다.

\section{결과 및 고찰}

\section{일반성분 및 무기질 비교}

일반성분 및 무기질 함량의 분석결과는 Table 1 과 같다. 쌀귀리 가루(대조구)의 일반성분은 수분, 조단백질, 조지방 및 조회분 함량이 각각 $8.4 \%, 15.7 \%, 10.0 \%$ 및 $1.8 \%$ 로 귀리 의 일반성분 중에서 조단백질 함량이 가장 높았다는 결과와 유사하였으나 조양 품종의 조단백질 함량이 $12.9 \%$ 라는 결 과보다 다소 높게 나타났다 $(31,32)$. 한편, 쌀귀리의 주요 무기질은 K $311.0 \mathrm{mg} \%, \mathrm{Mg} 132.7 \mathrm{mg} \%$ 및 Ca $65.5 \mathrm{mg} \%$ 로 총 무기질 $(529.9 \mathrm{mg} \%)$ 의 $96.1 \%$ 에 해당하였으며, $\mathrm{Fe}, \mathrm{Na}$, $\mathrm{Mn}, \mathrm{Zn}$, 및 $\mathrm{Cu}$ 등과 같은 무기질을 미량 함유하고 있는 것으로 나타났다. 이는 귀리의 주요 무기질이 $\mathrm{K}(468.1$ $\mathrm{mg} \%), \mathrm{Mg}(185.6 \mathrm{mg} \%), \mathrm{Ca}(165.5 \mathrm{mg} \%)$ 순이라는 결과와

\begin{tabular}{|c|c|c|c|c|c|}
\hline \multirow{2}{*}{\multicolumn{2}{|c|}{ Components }} & \multirow[b]{2}{*}{ Control } & \multicolumn{3}{|c|}{ Fractions of control } \\
\hline & & & $\begin{array}{l}\text { Fraction A } \\
(>250 \mu \mathrm{m})\end{array}$ & $\begin{array}{c}\text { Fraction B } \\
(160-250 \mu \mathrm{m})\end{array}$ & $\begin{array}{l}\text { Fraction } \mathrm{C} \\
(<160 \mu \mathrm{m})\end{array}$ \\
\hline \multicolumn{2}{|c|}{ Moisture (\%) } & $8.4 \pm 0.0^{\mathrm{cl})}$ & $8.9 \pm 0.2^{\mathrm{b}}$ & $9.2 \pm 0.1^{b}$ & $9.6 \pm 0.0^{\mathrm{a}}$ \\
\hline \multicolumn{2}{|c|}{ Crude protein $(\%)$} & $15.7 \pm 0.3^{\mathrm{b}}$ & $16.6 \pm 0.0^{\mathrm{a}}$ & $15.8 \pm 0.2^{\mathrm{b}}$ & $14.6 \pm 0.1^{c}$ \\
\hline \multicolumn{2}{|c|}{ Crude lipid (\%) } & $10.0 \pm 0.2^{\mathrm{a}}$ & $10.4 \pm 0.4^{\mathrm{a}}$ & $9.8 \pm 0.4^{\mathrm{ab}}$ & $9.6 \pm 0.1^{b}$ \\
\hline \multicolumn{2}{|c|}{ Crude ash (\%) } & $1.8 \pm 0.0^{\mathrm{b}}$ & $2.0 \pm 0.1^{\mathrm{a}}$ & $1.6 \pm 0.0^{c}$ & $1.4 \pm 0.0^{\mathrm{d}}$ \\
\hline \multirow{9}{*}{ Mineral (mg\%) } & K & $311.0 \pm 1.3^{\mathrm{b}}$ & $317.3 \pm 0.1^{\mathrm{a}}$ & $307.9 \pm 1.6^{c}$ & $246.8 \pm 0.8^{\mathrm{d}}$ \\
\hline & $\mathrm{Ca}$ & $65.5 \pm 0.4^{\mathrm{a}}$ & $65.4 \pm 0.2^{\mathrm{a}}$ & $64.9 \pm 0.2^{\mathrm{a}}$ & $50.9 \pm 0.4^{\mathrm{b}}$ \\
\hline & $\mathrm{Fe}$ & $6.0 \pm 0.0^{c}$ & $6.2 \pm 0.0^{\mathrm{b}}$ & $6.3 \pm 0.0^{\mathrm{a}}$ & $5.1 \pm 0.0^{\mathrm{c}}$ \\
\hline & $\mathrm{Na}$ & $5.7 \pm 0.0^{\mathrm{b}}$ & $6.2 \pm 0.1^{\mathrm{a}}$ & $5.6 \pm 0.0^{\mathrm{c}}$ & $4.3 \pm 0.0^{\mathrm{d}}$ \\
\hline & $\mathrm{Mg}$ & $132.7 \pm 0.6^{\mathrm{a}}$ & $133.7 \pm 0.8^{\mathrm{a}}$ & $133.7 \pm 0.6^{\mathrm{a}}$ & $102.2 \pm 0.3^{\mathrm{b}}$ \\
\hline & $\mathrm{Mn}$ & $5.6 \pm 0.0^{\mathrm{a}}$ & $5.6 \pm 0.0^{\mathrm{a}}$ & $5.6 \pm 0.0^{\mathrm{a}}$ & $4.7 \pm 0.0^{\mathrm{b}}$ \\
\hline & $\mathrm{Zn}$ & $2.8 \pm 0.0^{\mathrm{b}}$ & $2.8 \pm 0.0^{\mathrm{b}}$ & $3.1 \pm 0.0^{\mathrm{a}}$ & $2.5 \pm 0.0^{\mathrm{c}}$ \\
\hline & $\mathrm{Cu}$ & $0.5 \pm 0.0^{c}$ & $0.5 \pm 0.0^{c}$ & $0.9 \pm 0.0^{\mathrm{a}}$ & $0.7 \pm 0.0^{\mathrm{b}}$ \\
\hline & Total & $529.9 \pm 2.4^{\mathrm{b}}$ & $537.8 \pm 1.3^{\mathrm{a}}$ & $528.0 \pm 2.5^{\mathrm{b}}$ & $417.2 \pm 1.6^{c}$ \\
\hline
\end{tabular}

Table 1. Proximate and mineral composition of naked oat flours according to different particle sizes

\footnotetext{
${ }^{1)}$ Values are mean \pm SD $(n=3)$. Means with different superscript small letters in the same row are significantly different by Duncan's multiple test $(\mathrm{p}<0.05)$.
} 
유사한 조성이었다(31).

입도별로는 수분이 8.9-9.6\%, 조단백질이 $14.6-16.6 \%$, 조회 분이 $1.4-2.0 \%$, 무기질이 417.2-537.8 mg\%로 입도가 작아질 수록 수분은 증가하였으나 조단백질, 조지방, 조회분 및 무기질 함량은 감소하였다. 이는 귀리의 강층(bran)이 배유 (endosperm)보다 조단백, 조지방, 조회분 및 무기질 등의
영양성분을 더 많이 함유하고 있기 때문(4,33)으로, 입도별 분획과정 중에 귀리의 세포벽을 이루는 강층이 감소함으로 써 입도가 작아질수록 조단백질, 조지방, 조회분 및 무기질 함량이 감소할 뿐만 아니라 표면적이 넓어져 분획과정 중 공기에 존재하는 수분을 많이 흡착하여 수분이 증가하는 것으로 추정된다.

Table 2. Free amino acid composition of naked oat flours according to different particle sizes

\begin{tabular}{|c|c|c|c|c|c|}
\hline & \multirow[b]{2}{*}{ Components ${ }^{1)}$} & \multirow[b]{2}{*}{ Control } & \multicolumn{3}{|c|}{ Fractions of control } \\
\hline & & & $\begin{array}{l}\text { Fraction A } \\
(>250 \mu \mathrm{m})\end{array}$ & $\begin{array}{c}\text { Fraction B } \\
(160-250 \mu \mathrm{m})\end{array}$ & $\begin{array}{l}\text { Fraction C } \\
(<160 \mu \mathrm{m})\end{array}$ \\
\hline \multirow{10}{*}{$\begin{array}{l}\text { EAA } \\
(\mathrm{mg} \%)\end{array}$} & Threonine & $4.2 \pm 0.6^{(22)}$ & $3.5 \pm 0.0^{\mathrm{b}}$ & $4.2 \pm 0.6^{\mathrm{a}}$ & $3.5 \pm 0.0^{b}$ \\
\hline & Valine & $0.3 \pm 0.3^{\mathrm{a}}$ & $\mathrm{ND}^{3)}$ & $0.5 \pm 0.0^{\mathrm{a}}$ & $0.5 \pm 0.0^{\mathrm{a}}$ \\
\hline & Methionine & $3.8 \pm 0.3^{\mathrm{ab}}$ & $4.0 \pm 0.0^{\mathrm{a}}$ & $3.1 \pm 0.8^{\mathrm{b}}$ & $1.8 \pm 0.3^{\mathrm{c}}$ \\
\hline & Isoleucine & $2.0 \pm 0.5^{\mathrm{b}}$ & $1.5 \pm 0.0^{\mathrm{c}}$ & $3.8 \pm 2.8^{\mathrm{b}}$ & $6.8 \pm 0.3^{\mathrm{a}}$ \\
\hline & Leucine & $4.0 \pm 0.5^{\mathrm{b}}$ & $3.5 \pm 0.0^{\mathrm{c}}$ & $5.3 \pm 2.0^{\mathrm{b}}$ & $7.0 \pm 0.5^{\mathrm{a}}$ \\
\hline & Phenylalanine & $8.6 \pm 1.9^{\mathrm{ab}}$ & $10.8 \pm 0.3^{\mathrm{a}}$ & $8.0 \pm 0.9^{b}$ & $8.8 \pm 0.3^{\mathrm{b}}$ \\
\hline & Histidine & $12.2 \pm 3.6^{\mathrm{a}}$ & $8.0 \pm 0.0^{\mathrm{b}}$ & $11.6 \pm 4.4^{\mathrm{a}}$ & $6.3 \pm 0.3^{\mathrm{c}}$ \\
\hline & Tryptophan & $0.5 \pm 0.0^{\mathrm{a}}$ & $0.5 \pm 0.0^{\mathrm{a}}$ & $0.5 \pm 0.0^{\mathrm{a}}$ & $0.5 \pm 0.0^{\mathrm{a}}$ \\
\hline & Lysine & $3.5 \pm 0.0^{\mathrm{b}}$ & $3.5 \pm 0.0^{\mathrm{a}}$ & $3.5 \pm 0.0^{\mathrm{a}}$ & $3.5 \pm 0.0^{\mathrm{a}}$ \\
\hline & Total & $39.1 \pm 3.5^{\mathrm{a}}$ & $35.3 \pm 0.3^{\mathrm{b}}$ & $40.3 \pm 0.6^{\mathrm{a}}$ & $38.5 \pm 1.5^{\mathrm{a}}$ \\
\hline \multirow{21}{*}{$\begin{array}{l}\text { NEAA } \\
(\mathrm{mg} \%)\end{array}$} & Phophoserine & $3.7 \pm 0.3^{\mathrm{a}}$ & $4.0 \pm 0.0^{\mathrm{a}}$ & $3.8 \pm 0.6^{\mathrm{a}}$ & $4.3 \pm 0.3^{\mathrm{a}}$ \\
\hline & Phosphoethanol & $\mathrm{ND}$ & ND & $\mathrm{ND}$ & ND \\
\hline & Taurine & ND & $\mathrm{ND}$ & $\mathrm{ND}$ & $\mathrm{ND}$ \\
\hline & Aspartic acid & $34.0 \pm 1.3^{\mathrm{a}}$ & $21.0 \pm 0.5^{b}$ & $34.2 \pm 1.0^{\mathrm{a}}$ & $21.5 \pm 0.0^{\mathrm{b}}$ \\
\hline & Serine & $10.6 \pm 4.6^{\mathrm{ab}}$ & $5.3 \pm 0.3^{\mathrm{c}}$ & $11.9 \pm 2.5^{\mathrm{a}}$ & $8.8 \pm 0.3^{b}$ \\
\hline & Asparagine & $5.0 \pm 1.8^{\mathrm{a}}$ & $3.0 \pm 0.0^{\mathrm{b}}$ & $4.3 \pm 2.5^{\mathrm{ab}}$ & $1.5 \pm 0.0^{c}$ \\
\hline & Glutamic acid & $53.8 \pm 7.0^{\mathrm{ab}}$ & $46.3 \pm 0.3^{b}$ & $56.7 \pm 1.4^{\mathrm{a}}$ & $57.0 \pm 0.5^{\mathrm{a}}$ \\
\hline & a-Aminoadipic acid & ND & $\mathrm{ND}$ & $12.8 \pm 2.2^{\mathrm{b}}$ & $38.0 \pm 0.5^{\mathrm{a}}$ \\
\hline & Glycine & $6.7 \pm 1.4^{\mathrm{ab}}$ & $5.0 \pm 0.0^{\mathrm{c}}$ & $6.8 \pm 1.0^{\mathrm{a}}$ & $5.3 \pm 0.3^{\mathrm{b}}$ \\
\hline & Alanine & $38.8 \pm 7.2^{\mathrm{a}}$ & $19.0 \pm 0.5^{\mathrm{b}}$ & $38.3 \pm 8.0^{\mathrm{a}}$ & $17.3 \pm 0.3^{\mathrm{c}}$ \\
\hline & Citrulline & $3.8 \pm 3.3^{\mathrm{a}}$ & $\mathrm{ND}$ & $3.8 \pm 3.3^{\mathrm{a}}$ & $\mathrm{ND}$ \\
\hline & a-Aminobutyric acid & $25.5 \pm 3.0^{\mathrm{a}}$ & $22.0 \pm 0.5^{\mathrm{a}}$ & $18.3 \pm 5.4^{\mathrm{a}}$ & $0.8 \pm 0.3^{b}$ \\
\hline & Cystine & $58.3 \pm 0.4^{\mathrm{a}}$ & $58.8 \pm 0.3^{\mathrm{a}}$ & $49.7 \pm 4.4^{b}$ & $32.8 \pm 0.3^{\mathrm{c}}$ \\
\hline & Tyrosine & $5.4 \pm 0.6^{\mathrm{b}}$ & $7.3 \pm 0.3^{\mathrm{a}}$ & $3.8 \pm 0.2^{\mathrm{c}}$ & $2.5 \pm 0.0^{\mathrm{d}}$ \\
\hline & $\beta$-Alanine & $6.3 \pm 0.5^{\mathrm{b}}$ & $15.0 \pm 0.0^{\mathrm{a}}$ & $1.3 \pm 0.2^{\mathrm{c}}$ & ND \\
\hline & $\beta$-Aminoisobutyric acid & $53.8 \pm 6.3^{\mathrm{b}}$ & $118.8 \pm 0.3^{\mathrm{a}}$ & $20.1 \pm 2.2^{\mathrm{c}}$ & $17.3 \pm 0.3^{\mathrm{d}}$ \\
\hline & $\gamma$-Aminobutyric acid & $27.8 \pm 1.0^{\mathrm{b}}$ & $29.0 \pm 0.0^{\mathrm{a}}$ & $18.9 \pm 4.2^{\mathrm{C}}$ & $2.5 \pm 0.0^{\mathrm{d}}$ \\
\hline & Carnosine & $4.3 \pm 0.9^{d}$ & $10.0 \pm 0.0^{c}$ & $19.0 \pm 0.3^{\mathrm{b}}$ & $53.8 \pm 0.3^{\mathrm{a}}$ \\
\hline & Ornithine & $0.5 \pm 0.0^{\mathrm{b}}$ & $0.5 \pm 0.0^{\mathrm{b}}$ & $0.7 \pm 0.3^{\mathrm{ab}}$ & $1.0 \pm 0.0^{\mathrm{a}}$ \\
\hline & Ammonia & $3.7 \pm 1.9^{\mathrm{a}}$ & $1.5 \pm 0.0^{\mathrm{c}}$ & $3.9 \pm 1.7^{\mathrm{a}}$ & $2.0 \pm 0.0^{\mathrm{b}}$ \\
\hline & Total & $341.9 \pm 11.3^{\mathrm{b}}$ & $366.3 \pm 2.3^{\mathrm{a}}$ & $308.3 \pm 4.5^{\mathrm{c}}$ & $266.0 \pm 2.5^{\mathrm{d}}$ \\
\hline & ree amino acid content & $381.0 \pm 18.3^{\mathrm{b}}$ & $401.5 \pm 2.5^{\mathrm{a}}$ & $348.6 \pm 34.8^{c}$ & $304.5 \pm 4.0^{\mathrm{d}}$ \\
\hline
\end{tabular}

${ }^{1}$ EAA and NEAA are an abbreviation for essential amino acid and non essential amino acid, respectively.

${ }^{2}$ Values are mean $\pm \mathrm{SD} \quad(\mathrm{n}=3)$. Means with different superscript small letters in the same row are significantly different by Duncan's multiple test $(\mathrm{p}<0.05)$.

${ }^{3} \mathrm{ND}$ is an abbreviation for not detected. 
유리아미노산 함량 비교

유리아미노산 함량의 분석결과는 Table 2 와 같다. 대조구 의 유리아미노산 조성은 주로 비필수아미노산(non essential amino acid, NEAA)으로 이루어져 있으며, 필수아미노산 (essential amino acid, NAA) 함량은 총 유리아미노산의 $10.3 \%$ 인 $39.1 \mathrm{mg} \%$ 로 나타났다. 주요 유리아미노산은 NEAA 중에서는 glutamic acid(53.8 mg\%), cystine(58.3 $\mathrm{mg} \%)$, $\beta$-aminoisobutyric acid(53.8 $\mathrm{mg} \%)$ 등이었으며, EAA 중에서는 phenylalanine $(8.6 \mathrm{mg} \%)$ 과 histidine $(12.2 \mathrm{mg} \%)$ 이 었다. EAA는 인체에서 생성되지 않거나 생성되더라도 생 성량이 소량이기 때문에 음식의 섭취를 통하여 부족한 부분 을 공급해야 하는데 쌀, 밀, 보리 등과 같은 곡류보다는 귀리에 함유된 필수아미노산 함량이 높을 뿐만 아니라 귀리 는 쌀에 부족한 lysine 함량이 높아서 쌀을 주식으로 하는 우리에게 적합하다( 3,34$)$.

입도별로는 입도가 가장 작은 fraction C(304.5 mg\%)가 입도가 가장 큰 fraction $\mathrm{A}(401.5 \mathrm{mg} \%)$ 보다 총 유리아미노 산 함량이 $24.2 \%$ 감소하여 조단백질의 결과와 유사하였다. 이는 fraction $\mathrm{A}$ 에서 가장 높은 함량을 나타냈던 $\beta$ -aminoisobutyric acid 함량이 $118.8 \mathrm{mg} \%$ 에서 $17.3 \mathrm{mg} \%$ 로 감소한 것이 주된 원인으로 추정된다. 또한 fraction $\mathrm{A}$ 는 대조구보다 methionine, phenylalanine, histidine 등과 같은 유리아미노산 함량이 높아서 강층이 배유보다 아미노산 함량이 높았다는 결과와 유사하였다 $(4,33)$. 그러나 isoleucine, glutamic acid, carnosine 등과 같은 일부 아미노산은 입도가 작아질수록 함량이 증가하여 다른 경향을 보이기도 하 였다.

\section{탄수화물 조성 비교}

탄수화물 조성의 결과는 Table 3 과 같다. 대조구의 탄수 화물 조성은 총 전분, 아밀로스, 손상전분, 총 식이섬유, $\beta$-glucan 및 총 유리당 함량이 각각 $56.4 \%, 21.4 \%, 11.7 \%$,
$11.0 \%, 4.7 \%$ 및 $2,555.3 \mathrm{mg} \%$ 로, 이중 총 전분함량이 가장 높게 나타났다. 이는 귀리의 전분함량이 59.8-61.5\%이며 전분의 $21.3 \%$ 가 아밀로스로 구성되어져 있다는 기존의 연 구결과와 유사하였다(35,36). 또한 총 식이섬유와 $\beta$-glucan 함량은 각각 $10.3-13.1 \%$ 와 $4.7-4.9 \%$ 이라는 결과와도 유사 하였다 $(6,11,32,37)$. 한편 귀리의 유리당 조성은 glucose $(1,340 \mathrm{mg} \%)$ 와 maltose $(1,360 \mathrm{mg} \%)$ 가 fructose $(560 \mathrm{mg} \%)$ 보 다 많이 함유되어있다는 결과와 유사하였다(31).

입도별로는 총 전분, 아밀로스 및 손상전분의 함량이 fraction $\mathrm{A}$ 에서 각각 $53.6 \% 19.2 \%$ 및 $10.1 \%$, fraction $\mathrm{C}$ 에서 각각 $61.6 \%, 25.3 \%$ 및 $15.5 \%$ 로 입도가 작아질수록 증가하 였다. 쌀, 보리, 밀, 귀리와 같은 곡류는 가공제품으로 제조 하기 위한 전 단계로 제분을 하게 되는데, 이 때 치밀한 미셀구조의 생전분(native starch)이 분쇄되면서 입도는 작 아짐과 동시에 분쇄의 충격으로 전분의 일부가 미세다공성 구조의 손상전분(damaged starch)으로 전환된다(38). 또한, 손상전분은 다공성 구조의 특성상 생전분보다 전분분해효 소 뿐만 아니라 수화과정 중에 쉽게 영향을 받게 되어 가공 적성에 영향을 미치기 때문에 목적하는 가공제품에 맞는 적절한 입도를 파악하는 것이 매우 중요하다(39). 반면에 비전분다당류로 분류되는 총 식이섬유와 $\beta$-glucan의 함량 은 fraction $\mathrm{A}$ 에서 각각 $15.4 \%$ 와 $5.2 \%$, fraction $\mathrm{C}$ 에서 각각 $9.2 \%$ 와 $4.0 \%$ 로 입도가 작아질수록 감소하여 전분이나 전 분과 관련 있는 성분들(아밀로스와 손상전분)과는 다른 경 향을 보였다. 이는 세포벽 구성성분인 식이섬유와 $\beta$-glucan 이 전분보다 결합력이 강하여 동일한 제분조건에서 전분에 비해 큰 입도를 갖기 때문으로 판단된다(13).

\section{지방산 조성 비교}

지방산 조성의 결과는 Table 4 와 같다. 대조구의 주요 지방산은 포화지방산 중에서는 palmitic acid(15.4\%)이었으 며, 불포화지방산 중에서는 oleic $\operatorname{acid}(47.7 \%)$ 와 linoleic

Table 3. Carbohydrate composition of naked oat flours according to different particle sizes

\begin{tabular}{|c|c|c|c|c|c|}
\hline \multirow{2}{*}{\multicolumn{2}{|c|}{ Components }} & \multirow[b]{2}{*}{ Control } & \multicolumn{3}{|c|}{ Fractions of control } \\
\hline & & & $\begin{array}{l}\text { Fraction A } \\
(>250 \mu \mathrm{m})\end{array}$ & $\begin{array}{c}\text { Fraction B } \\
(160-250 \mu \mathrm{m})\end{array}$ & $\begin{array}{l}\text { Fraction C } \\
(<160 \mu \mathrm{m})\end{array}$ \\
\hline \multicolumn{2}{|c|}{ Total starch (\%) } & $56.4 \pm 0.4^{\mathrm{cl})}$ & $53.6 \pm 0.4^{\mathrm{d}}$ & $58.5 \pm 0.2^{\mathrm{b}}$ & $61.6 \pm 0.6^{\mathrm{a}}$ \\
\hline \multicolumn{2}{|c|}{ Amylose (\%) } & $21.4 \pm 0.3^{\mathrm{c}}$ & $19.2 \pm 0.5^{\mathrm{d}}$ & $23.6 \pm 0.3^{\mathrm{b}}$ & $25.3 \pm 0.1^{\mathrm{a}}$ \\
\hline \multicolumn{2}{|c|}{ Starch damage $(\%)$} & $11.7 \pm 0.4^{\mathrm{c}}$ & $10.1 \pm 0.0^{\mathrm{d}}$ & $13.0 \pm 0.2^{\mathrm{b}}$ & $15.5 \pm 0.4^{\mathrm{a}}$ \\
\hline \multicolumn{2}{|c|}{ Total dietary fiber $(\%)$} & $11.0 \pm 0.5^{\mathrm{c}}$ & $15.4 \pm 0.4^{\mathrm{a}}$ & $12.5 \pm 0.3^{\mathrm{b}}$ & $9.2 \pm 0.1^{\mathrm{d}}$ \\
\hline \multicolumn{2}{|c|}{ ß-Glucan (\%) } & $4.7 \pm 0.1^{\mathrm{b}}$ & $5.2 \pm 0.2^{\mathrm{a}}$ & $4.3 \pm 0.0^{c}$ & $4.0 \pm 0.1^{\mathrm{d}}$ \\
\hline \multirow{4}{*}{ Free sugar (mg\%) } & Glucose & $1,231.5 \pm 21.3^{b}$ & $1,740.4 \pm 37.4^{\mathrm{a}}$ & $845.7 \pm 12.4^{c}$ & $645.2 \pm 17.8^{d}$ \\
\hline & Fructose & $478.2 \pm 11.2^{\mathrm{b}}$ & $674.4 \pm 25.1^{\mathrm{a}}$ & $354.5 \pm 18.2^{\mathrm{c}}$ & $300.1 \pm 12.7^{\mathrm{d}}$ \\
\hline & Maltose & $845.6 \pm 10.6^{b}$ & $1004.3 \pm 36.2^{\mathrm{a}}$ & $738.2 \pm 14.8^{c}$ & $568.6 \pm 20.1^{\mathrm{d}}$ \\
\hline & Total & $2,555.3 \pm 43.1^{b}$ & $3,419.1 \pm 98.7^{\mathrm{a}}$ & $1,938.4 \pm 45.4^{\mathrm{c}}$ & $1,513.9 \pm 50.6^{d}$ \\
\hline
\end{tabular}

\footnotetext{
${ }^{1)}$ Values are mean $\pm \mathrm{SD}(\mathrm{n}=3)$. Means with different superscript small letters in the same row are significantly different by Duncan's multiple test $(\mathrm{p}<0.05)$.
} 
Table 4. Fatty acid composition of naked oat flours according to different particle sizes

\begin{tabular}{|c|c|c|c|c|c|}
\hline & \multirow[b]{2}{*}{ Components } & \multirow[b]{2}{*}{ Control } & \multicolumn{3}{|c|}{ Fractions of control } \\
\hline & & & $\begin{array}{l}\text { Fraction A } \\
(>250 \mu \mathrm{m})\end{array}$ & $\begin{array}{l}\text { Fraction B } \\
(160-250 \mu \mathrm{m})\end{array}$ & $\begin{array}{l}\text { Fraction C } \\
(<160 \mu \mathrm{m})\end{array}$ \\
\hline \multirow{5}{*}{$\begin{array}{l}\mathrm{SFA}^{1)} \\
(\%)\end{array}$} & Myristic acid (C14:0) & $0.2 \pm 0.0^{(2)}$ & $0.2 \pm 0.0^{c}$ & $0.3 \pm 0.0^{b}$ & $0.4 \pm 0.0^{\mathrm{a}}$ \\
\hline & Palmitic acid (C16:0) & $15.4 \pm 0.1$ & $15.5 \pm 2.1$ & $15.5 \pm 0.2$ & $15.4 \pm 2.3$ \\
\hline & Stearic acid $(\mathrm{C} 18: 0)$ & $2.0 \pm 0.0$ & $1.9 \pm 0.3$ & $2.1 \pm 0.0$ & $2.0 \pm 0.4$ \\
\hline & Arachidic acid (C20:0) & $0.2 \pm 0.0^{\mathrm{c}}$ & $0.2 \pm 0.0^{\mathrm{c}}$ & $0.3 \pm 0.0^{\mathrm{b}}$ & $0.4 \pm 0.0^{\mathrm{a}}$ \\
\hline & Total & $17.8 \pm 0.2$ & $17.7 \pm 1.8$ & $18.2 \pm 0.3$ & $18.2 \pm 2.7$ \\
\hline \multirow{5}{*}{$\begin{array}{l}\text { USFA } \\
(\%)\end{array}$} & Oleic acid (C18:1) & $47.7 \pm 0.6$ & $46.9 \pm 6.6$ & $47.1 \pm 0.4$ & $47.5 \pm 7.7$ \\
\hline & Linoleic aicd (C18:2) & $32.7 \pm 0.5$ & $33.6 \pm 4.7$ & $32.9 \pm 0.1$ & $32.8 \pm 5.0$ \\
\hline & Eicosenoic acid(C20:1) & $1.0 \pm 0.0^{\mathrm{a}}$ & $0.8 \pm 0.1^{\mathrm{bc}}$ & $0.9 \pm 0.0^{\mathrm{b}}$ & $0.8 \pm 0.0^{\mathrm{c}}$ \\
\hline & Linolenic acid (C18:3) & $0.8 \pm 0.0$ & $1.0 \pm 0.3$ & $0.9 \pm 0.0$ & $0.8 \pm 0.0$ \\
\hline & Total & $82.2 \pm 0.2^{\mathrm{NS} 3)}$ & $82.3 \pm 1.8$ & $81.8 \pm 0.3$ & $81.8 \pm 2.7$ \\
\hline
\end{tabular}

${ }^{1)}$ SFA and USFA are an abbreviation for saturated fatty acid and unsaturated fatty acids, respectively.

${ }^{2)}$ Values are mean $\pm \mathrm{SD}(\mathrm{n}=3)$. Means with different superscript small letters in the same row are significantly different by Duncan's multiple test $(\mathrm{p}<0.05)$.

${ }^{3)} \mathrm{NS}$, not significant at $\mathrm{p}=0.05$.

$\operatorname{acid}(32.7 \%)$ 이었다. 이는 귀리의 지방산은 포화지방산보다 불포화지방산이 높으며 주요 지방산이 palmitic acid, oleic acid, linoleic acid 등이라는 결과와 유사하였다 $(31,40)$.

입도별로는 포화지방산이 $17.7-18.2 \%$, 불포화지방산이 81.8-82.3\%로 유사하였으며, 주요 지방산의 조성도 큰 차이 를 보이지 않았다. 이와 같이 지방산 조성이 일반성분, 무기 질, 유리아미노산 및 탄수화물 함량과 달리 입도별로 차이 를 보이지 않는 것은 본 결과가 지방산의 함량이 아닌 단순 히 추출된 지방산 조성비만을 비교분석하였기 때문이며, 이는 부위별 지방산 조성으로 볼 때, 강층이 배유층보다 지방산 함량이 높지만 조성비는 비슷하였다는 결과와 유사 하였다 $(1,40)$.

\section{물리적 특성 비교}

물리적 특성의 결과는 Table 5와 같다. 대조구의 색도는 $\mathrm{L}$ 값이 $75.3, \mathrm{a}$ 값과 $\mathrm{b}$ 값이 각각 0.3 과 13.1 로 기존에 보고된 귀리가루의 색도(86.3, 0.6 및 8.8)보다 L과 a 값은 낮게 나타났으나 $\mathrm{b}$ 값은 높게 나타났다(41). 호화특성은 최고점 도가 $263.8 \mathrm{RVU}$, 최저점도가 $155.6 \mathrm{RVU}$, 그리고 최종점도 가 $399.3 \mathrm{RVU}$ 이었다. 특히 $95^{\circ} \mathrm{C}$ 에서 $50^{\circ} \mathrm{C}$ 로 냉각하면서 나타나는 치반점도가 $243.7 \mathrm{RVU}$ 로 호화된 전분의 점도가 급격히 증가하는 노화현상이 관찰되었는데, 이는 대조구의 아밀로스 함량이 $21.4 \%$ 라는 특성을 반영한 것으로 추정된 다(41).

입도별로는 $\mathrm{L}, \mathrm{a}$ 및 $\mathrm{b}$ 값이 fraction $\mathrm{A}$ 에서 74.7, 0.1 및

Table 5. Physical property of naked oat flours according to different particle sizes

\begin{tabular}{|c|c|c|c|c|c|}
\hline \multirow{2}{*}{\multicolumn{2}{|c|}{ Physical property }} & \multirow[b]{2}{*}{ Control } & \multicolumn{3}{|c|}{ Fractions of control } \\
\hline & & & $\begin{array}{l}\text { Fraction A } \\
(>250 \mu \mathrm{m})\end{array}$ & $\begin{array}{l}\text { Fraction B } \\
(160-250 \mu \mathrm{m})\end{array}$ & $\begin{array}{l}\text { Fraction C } \\
(<160 \mu \mathrm{m})\end{array}$ \\
\hline \multirow{3}{*}{ Hunter's value } & $\mathrm{L}$ & $75.3 \pm 0.1^{\mathrm{cl})}$ & $74.7 \pm 0.0^{\mathrm{d}}$ & $75.8 \pm 0.2^{b}$ & $77.8 \pm 0.0^{\mathrm{a}}$ \\
\hline & $\mathrm{a}$ & $0.3 \pm 0.0^{\mathrm{a}}$ & $0.1 \pm 0.1^{\mathrm{b}}$ & $-0.2 \pm 0.0^{c}$ & $-0.6 \pm 0.1^{d}$ \\
\hline & $\mathrm{b}$ & $13.1 \pm 0.1^{\mathrm{a}}$ & $12.8 \pm 0.1^{\mathrm{b}}$ & $12.7 \pm 0.0^{\mathrm{b}}$ & $12.1 \pm 0.0^{\mathrm{c}}$ \\
\hline \multirow{5}{*}{ Pasting property ${ }^{2)}$} & Peak viscosity (RVU) & $263.8 \pm 1.3^{c}$ & $252.2 \pm 3.1^{d}$ & $301.5 \pm 2.1^{b}$ & $311.4 \pm 1.8^{\mathrm{a}}$ \\
\hline & Trough (RVU) & $155.6 \pm 1.5^{\mathrm{a}}$ & $143.5 \pm 2.3^{\mathrm{b}}$ & $123.5 \pm 0.2^{\mathrm{d}}$ & $124.0 \pm 0.2^{\mathrm{c}}$ \\
\hline & Final viscosity (RVU) & $399.3 \pm 1.2^{c}$ & $324.8 \pm 2.0^{\mathrm{d}}$ & $463.0 \pm 0.9^{\mathrm{b}}$ & $490.0 \pm 4.3^{\mathrm{a}}$ \\
\hline & Break down (RVU) & $108.1 \pm 0.3^{c}$ & $108.7 \pm 0.8^{c}$ & $179.3 \pm 0.8^{\mathrm{b}}$ & $187.0 \pm 1.0^{\mathrm{a}}$ \\
\hline & Setback (RVU) & $243.7 \pm 2.7^{c}$ & $181.3 \pm 0.3^{d}$ & $340.8 \pm 2.3^{\mathrm{b}}$ & $365.5 \pm 3.6^{\mathrm{a}}$ \\
\hline
\end{tabular}

\footnotetext{
${ }^{1)}$ Values are mean \pm SD ( $\mathrm{n}=3$ ). Means with different superscript small letters in the same row are significantly different by Duncan's multiple test $(\mathrm{p}<0.05)$.

${ }^{2}$ Break down value is a difference between peak viscosity and trough, setback value is a difference between final viscosity and trough.
} 
12.8 이었고, fraction C에서 77.8, -0.6 및 12.1로 나타나서 입도가 작아질수록 $\mathrm{L}$ 값은 소폭 증가하였으나 $\mathrm{a}$ 와 $\mathrm{b}$ 값은 소폭 감소하였다. 이는 귀리의 입도가 작아질수록 밝아진 다는 결과와 유사하였다(42). 한편 호화특성의 경우, 입도 가 감소할수록 최고점도(252.2-311.4 RVU), 최종점도 (324.8-490.8 RVU), 강하점도(108.7-187.0 RVU) 및 치반점 도(181.3-365.5 RVU)가 증가하였는데, 이는 입도가 작아질 수록 전분과 amylose 함량의 증가로 점도가 증가하였기 때문으로 추정된다. 따라서 입도에 따른 영양성분의 조성 변화가 물리적 특성에 영향을 준다는 결과와 유사하였다 (43).

\section{항산화 성분 및 항산화 활성 비교}

항산화 성분 및 항산화 활성의 결과는 Table 6 과 같다. 대조구의 $\mathrm{TPC}$ 와 $\mathrm{TFC}$ 는 각각 $237.8 \mathrm{\mu g} / \mathrm{g}$ 와 $90.9 \mathrm{\mu g} / \mathrm{g}$ 이었으 며, 이는 귀리의 $\mathrm{TPC}$ 가 239-662 $\mu \mathrm{g} / \mathrm{g}$ 이라고 보고한 기존의 결과와 유사하였다(44,45). 항산화 활성은 항산화기작이 다 른 3개(DPPH radical assay, ABTS radical cation assay 및 reducing power)의 항산화 활성분석에서 각각 $57.3 \%, 53.4 \%$ 및 0.23 으로 나타났으며, 이상의 항산화 활성은 vitamin $\mathrm{E}(\mathrm{totols})$, phytic acid, 페놀성 화합물 등과 같은 다양한 항산 화 성분들이 존재하기 때문으로 판단된다(46).

입도별로는 fraction $\mathrm{A}$ 에서 fraction $\mathrm{C}$ 로 입도가 작아질수 록 $\mathrm{TPC}$ 와 $\mathrm{TFC}$ 는 각각 1.5 배와 2.8 배 감소하였으며, 각 항산 화 활성에서도 유사한 경향이었다. 특히, 피어슨 상관회귀 분석으로 산출한 결정계수(correlation determination coefficient, $\mathrm{R}^{2}$ ) 값이 $\mathrm{TPC}$ 가 0.87 이상을, $\mathrm{TFC}$ 가 0.81 이상을 나타내어 높은 상관성을 보였다. 이는 귀리의 페놀성 화합 물이 세포벽에 단백질과 같이 결합한 상태로 존재하기 때문 에 배유보다는 강층에 주로 존재하여 $420 \mu \mathrm{m}$ 이상의 입도 가 큰 분획이 $420 \mu \mathrm{m}$ 이하의 분획보다 $\mathrm{TPC}$ 와 항산화 활성
이 높았다는 결과와 유사하였다(12,14,47).

결과적으로 입도에 따른 영양성분의 조성변화가 이화학 적 특성 및 항산화 활성에 영향을 미치는 것으로 나타나 제빵, 제면 등의 가공제품에 적합한 입도의 쌀귀리 가루를 제조한다면 쌀귀리의 활용도를 높일 수 있을 것으로 기대 된다.

\section{요 약}

본 연구에서는 영양학적 가치가 높은 쌀귀리의 식품산업 이용률을 높이고자 쌀귀리를 입도별로 제조하여 이들의 이화학적 특성 및 항산화 활성을 비교하였다. 쌀귀리의 조 단백질, 조지방 및 조회분 함량이 각각 $15.7 \%, 10.0 \%$ 및 $1.8 \%$ 이었으며, 입도가 작아질수록 이들의 함량은 감소하 였다. 주요 유리아미노산은 비필수아미노산 중에서는 cystine(58.3 mg\%), $\beta$-aminoisobutyric acid(53.8 mg\%) 등, 필수아미노산 중에서는 phenylalanine $(8.6 \mathrm{mg} \%)$ 과 histidine $(12.2 \mathrm{mg} \%)$ 이었으며, 입도가 작아질수록 함량은 감소하였 다. 총 전분, 아밀로스, 손상전분, 총 식이섬유, $\beta$-glucan 및 총 유리당 함량은 각각 $56.4 \%, 21.4 \%, 11.7 \%, 11.0 \%$, $4.7 \%$ 및 $2,555.3 \mathrm{mg} \%$ 이었으며, 입도가 작아질수록 총 전분, 아밀로스 및 손상전분의 함량은 감소한 반면에 총 식이섬유 와 B-glucan의 함량은 증가하였다. 색도는 L 값이 75.3, a 값이 0.3 및 b 값이 13.1 이었으며, 입도가 작아질수록 $\mathrm{L}$ 값은 증가하였으나 $\mathrm{a}$ 와 $\mathrm{b}$ 값은 감소하였다. 호화특성은 최 고점도가 $263.8 \mathrm{RVU}$, 최저점도가 $155.6 \mathrm{RVU}$ 및 최종점도 가 $399.3 \mathrm{RVU}$ 이었으며, 입도가 작아질수록 최고점도와 최 종점도는 증가하였다. TPC, TFC 및 항산화 활성(DPPH radical assay, ABTS radical cation assay 및 reducing power) 은 각각 $237.8 \mu \mathrm{g} / \mathrm{g}, 90.9 \mu \mathrm{g} / \mathrm{g}, 57.3 \%, 53.4 \%$ 및 0.23 이었으

Table 6. Total phenolic content, total flavonoid content, and antioxidant activity of naked oat flours according to different particle sizes

\begin{tabular}{|c|c|c|c|c|c|}
\hline & \multirow[b]{2}{*}{ Components } & \multirow[b]{2}{*}{ Control } & \multicolumn{3}{|c|}{ Fractions of control } \\
\hline & & & $\begin{array}{l}\text { Fraction A } \\
(>250 \mu \mathrm{m})\end{array}$ & $\begin{array}{l}\text { Fraction B } \\
(160-250 \mu \mathrm{m})\end{array}$ & $\begin{array}{l}\text { Fraction C } \\
(<160 \mu \mathrm{m})\end{array}$ \\
\hline & Total phenolic content ${ }^{1)}(\mu \mathrm{g} / \mathrm{g})$ & $237.8 \pm 7.1^{b 4)}$ & $281.3 \pm 14.7^{\mathrm{a}}$ & $217.5 \pm 5.4^{\mathrm{c}}$ & $187.5 \pm 1.8^{\mathrm{d}}$ \\
\hline & Total flavonoid content $\left.{ }^{2}\right)(\mu \mathrm{g} / \mathrm{g})$ & $90.9 \pm 6.9^{b}$ & $123.3 \pm 0.8^{\mathrm{a}}$ & $54.6 \pm 2.2^{\mathrm{c}}$ & $43.5 \pm 1.7^{\mathrm{d}}$ \\
\hline & DPPH radical assay (\%) & $57.3 \pm 0.4^{b}$ & $63.8 \pm 0.9^{\mathrm{a}}$ & $54.3 \pm 1.0^{\mathrm{c}}$ & $49.8 \pm 0.9^{d}$ \\
\hline & ABTS radical cation assay $(\%)$ & $53.4 \pm 0.8^{\mathrm{b}}$ & $55.2 \pm 0.8^{\mathrm{a}}$ & $49.3 \pm 0.7^{\mathrm{c}}$ & $42.4 \pm 0.9^{d}$ \\
\hline & Reducing power & $0.23 \pm 0.00^{\mathrm{b}}$ & $0.25 \pm 0.00^{\mathrm{a}}$ & $0.21 \pm 0.00^{c}$ & $0.19 \pm 0.01^{\mathrm{d}}$ \\
\hline \multirow{3}{*}{$\begin{array}{l}\text { Regression } \\
\text { analysis }\end{array}$} & DPPH radical assay (\%) & \multicolumn{2}{|c|}{$\mathrm{Y}=0.150 \mathrm{X}_{1}+21.694\left(\mathrm{R}^{2}=0.99\right)$} & \multicolumn{2}{|c|}{$\mathrm{Y}=0.158 \mathrm{X}_{2}+43.947\left(\mathrm{R}^{2}=0.94\right)$} \\
\hline & ABTS radical cation assay (\%) & \multicolumn{2}{|c|}{$\mathrm{Y}=0.134 \mathrm{X}_{1}+19.024 \quad\left(\mathrm{R}^{2}=0.87\right)$} & \multicolumn{2}{|c|}{$\mathrm{Y}=0.141 \mathrm{X}_{2}+39.058\left(\mathrm{R}^{2}=0.81\right)$} \\
\hline & Reducing power & \multicolumn{2}{|c|}{$\mathrm{Y}=0.006 \mathrm{X}_{1}+0.076\left(\mathrm{R}^{2}=0.97\right)$} & \multicolumn{2}{|c|}{$\mathrm{Y}=0.007 \mathrm{X}_{2}+0.168 \quad\left(\mathrm{R}^{2}=0.98\right)$} \\
\hline
\end{tabular}

\footnotetext{
${ }^{1)}$ Total phenolic content expressed as $\mu \mathrm{g}$ gallic acid equivalent per $\mathrm{g}$.

${ }^{2}$ Total flavonoid content expressed as $\mu \mathrm{g}$ catechin equivalent per g.

${ }^{3)} \mathrm{X}_{1}, \mathrm{X}_{2}, \mathrm{Y}$, and $\mathrm{R}$ represent total phenolic content, total flavonoid content, each antioxidant activity, and correlation coefficient, respectively.

${ }^{4}$ Values are mean $\pm \mathrm{SD}(\mathrm{n}=3)$. Means with different superscript small letters in the same row are significantly different by Duncan's multiple test $(\mathrm{p}<0.05)$.
} 
며, 입도가 작아질수록 항산화 성분 및 항산화 활성은 감소 하였다. 한편 $\mathrm{TPC}$ 와 $\mathrm{TFC}$ 에 관한 각 항산화 활성의 결정계 수(correlation determination coefficient, $\mathrm{R}^{2}$ ) 값이 각각 0.87 이상과 0.81 이상으로 나타나 항산화 성분과 항산화 활성은 상관성을 보였다.

\section{References}

1. Zhou M, Robards K, Glennie-Holmes M, Helliwell S (1999) Oat lipids. J Am oil Chem Soc, 76, 159-169

2. Manolache FA, Hanganu A, Duta DE, Belc N, Marin DI (2013) The physico-chemical and spectroscopic composition characterization of oat grains and oat oil samples. Rev Chim, 64, 45-48

3. Biel W, Bobko K, Maciorowski R (2009) Chemical composition and nutritive value of husked and naked oats grain. J Cereal Sci, 49, 413-418

4. Pomeranz Y, Youngs VL, Robbins GS (1973) Protein content and amino acid composition of oat species and tissues. Cereal Chem, 50, 702-707

5. Lee YT (1996) Physicochemical characteristics and physiological functions of $\beta$-glucans in barley and oats. Korean J Crop Sci, 41, 10-24

6. Han OK, Park HH, Park TI, Seo JH, Park KH, Kim JG, Heo HY, Hong YG, Kim DH (2008) A new early-heading and high-yielding naked oat cultivar for human consumption, 'Choyang'. Korean J Breed Sci, 40, $512-516$

7. KMFDS (2016) Analysis report for annual production of functional food in 2016. Korean Ministry of Food and Drug Safety, Seoul, Korea, p 1-12

8. Lee NY (2013) Starch and quality characteristic of Korean rice cultivar with waxy and non-waxy type. Korean J Crop Sci, 58, 226-231

9. Son CG (2014) Progress of functional food in Korea and strategy of Korean medicine. J Korean Med, 35, 68-74

10. Seo YK, Whang K (1998) In vitro cholesterol adsorption activity of oat gum. J Korean Soc Food Sci Nutr, 27, 785-788

11. Dhingra D, Michael M, Rajput H, Patil RT (2012) Dietary fibre in foods: a review. J Food Sci Technol, 49, 255-266

12. Gray DA, Auerbach RH, Hill S, Wang R, Campbell, GM, Webb C, South JB (2000) Enrichment of oat antioxidant activity by dry milling and sieving. J Cereal Sci, 32, 89-98
13. Jeong HS, Kang TS, Jung IS, Park HJ, Min YK (2003) $\beta$-glucan contents with different particle size and varieties of barley and oats. Korean J Food Sci Technol, 35, 610-616

14. Peterson DM, Emmons CL, Hibbs AH (2001) Phenolic antioxidant and antioxidant activity in pearling fractions of oat groats. J Cereal Sci, 33, 97-103

15. AOAC (1996) Official Methods of Analysis. $15^{\text {th }} \mathrm{ed}$, Association of Official Analytical Chemists, Washington DC, USA, p 1121-1180

16. KFDA (2005) Korea Food and Drug Administration. Food Code. Korean Foods Industry Association, Seoul, Korea, p 358-364

17. Spackman DH, Stein WH, Moore S (1958) Automatic recording apparatus for use in chromatography of amino acids. Anal chem, 30, 1190-1206

18. McCleary BV, Solah V, Gibson TS (1994) Quantitative measurement of total starch in cereal flours and products. J Cereal Sci, 20, 51-58

19. Williams WB, Cuvelier ME, Berset C (1995) Use of a free radical method to evaluate antioxidant activity. Lebensmn Wiss Technol, 28, 25-30

20. Boyaci IH, Williams PC, Koksel H (2004) A rapid method for the estimation of damaged starch in wheat flour. J Cereal Sci, 39, 139-145

21. Prosky L, Asp NG, Schweizer TF, Devries JW, Furdal I (1998) Determination of insoluble, soluble and total dietary fiber in foods and food products, Interlaboratory study. J Assoc Off Anal Chem, 71, 1017-1025

22. McCleary BV, Glennie-Holmes M (1985) Enzymic quantification of $(1 \rightarrow 3),(1 \rightarrow 4)-\beta$-D-glucan in barley and malt. J Inst Brew, 91, 285-295

23. Cho IK, Jin SW, Kim YD (2009) Analysis of components in the parts of Opuntia ficus indica from Shinan Korea. Korean J Food Preserv, 16, 742-746

24. Cha MN, Jun HI, Song GS, Kim YS (2012) The Effects of germination conditions on GABA and the nutritional components of barley. J Food Sci Technol, 44, 41-47

25. Dewanto V, Wu X, Adonm KK, Liu RH (2002) Thermal processing enhances the nutritional value of tomatoes by increasing total antioxidant activity. J Agric Food Chem, 50, 3010-3014

26. Jia Z, Tang M, Wu J (1999) The determination of flavonoid contents in mulberry and they scavenging effects on superoxide radicals. Food Chem, 64, 555-559

27. Williams WB, Cuvelier ME, Berset C (1995) Use of a free radical method to evaluate antioxidant activity. 
Lebenson Wiss Technol, 28, 25-30

28. Arts MJTJ, Haenen GRMM, Voss HP, Bast A (2004) Antioxidant capacity of reaction products limits the applicability of the trolox equivalent antioxidant capacity (TEAC) assay. Food Chem Toxicol, 42, 45-49

29. Oyaizu M (1986) Studies on products of browning reaction-antioxidant activities of products of browning reaction prepared from glucoamin. Japanese J Nutr Diet, 44, 307-315

30. SAS (2004) SAS/STAT 9.1 User's Guide. SAS Institute Inc, Cary, NC, USA, p 421-480

31. Kim HY, Hwang IG, Woo KS, Kim KH, Kim KJ, Lee CK, Lee JS, Jeong HS (2010) Chemical components changes of winter cereal crops with germination. J Korean Soc Food Sci Nutr, 39, 1700-1704

32. Han OK, Park HH, Heo HY, Park TI, Seo JH, Park KH, Kim JG, Hong YG, Kim DH (2008) A new naked oat cultivar for human consumption, 'Daeyang' with high-yielding and good-quality. Korean J Breed Sci, 41, 56-60

33. Hahn JD, Chung TK, Baker DH (1990) Nutritive value of oat flour and oat bran. J Anim Sci, 68, 4253-4260

34. Kosieradzka I, Fabijanska M (2001) Comparison of the nutritive value of naked and husked oat protein with wheat and maize. J Anim Feed Sci, 10, 309-314

35. Hoover R, Senanayake SPJN (1996) Composition and physicochemical properties of oat starches. Food Res Int, 29, 15-26

36. Tian B, Xie B, Shi J, Wu J, Cai Y, Xu T, Xue SJ, Deng Q (2010) Physicochemical changes of oat seeds during germination. Food Chem, 119, 1195-1200

37. Seo YK, Whang K (1998) In vitro cholesterol adsorption activity of oat gum. J Korean Soc Food Sci Nutr, 27, 785-788
38. Jun HI, Yang EJ, Kim YS, Song GS (2008) Effect of dry and wet millings on physicochemical properties of black rice flours. J Korean Soc Food Sci Nutr, 37, 900-907

39. Meuser F, Klingler RW, Niediek EK (1978) Characterization of mechanically modified starch. Starch, 30, 376-384

40. Leonova S, Shelenga T, Hamberg M, Konarev AV, Loskutov I, Carlsson AS (2008) Analysis of oil composition in cultivars and wild species of oat (Avena sp.). J Agric Food Chem, 56, 7983-7991

41. Kim CH, Tie J, Ryu GH (2012) Effect of moisture content on physical properties of extruded creal flours. J Korean Soc Food Sci Nutr, 41, 1603-1610

42. Lee YT, Seog HM, Cho MK, Kim SS (1996) Physicochemical properties of hull-less barley flours prepared with different ginding mills. Korean J Food Sci Technol, 28, 1078-1083

43. Ovando-Martínez M, Whitney K, Reuhs BL, Doehlert DC, Simsek S (2013) Effect of hydrothermal treatment on physicochemical and digestibility properties of oat starch. Food Res Int, 52, 17-25

44. Brindzova L, Certik M, Rapta P, Zalibera M, Mikulajova A, Takacsova M (2008) Antioxidant activity, $\beta$-glucan and lipid contents of oat varieties. Czech J Food Sci, 26, 163-173

45. Yu L, Perret J, Davy B, Wilson J, Melby CL (2002) Antioxidant properties of cereal products. J Food Sci, 67, 2600-2603

46. Peterson DM (2001) Oat antioxidants. J Cereal Sci, 33, 115-129

47. Guo X, Yao H (2006) Fractionation and characterization of tartary buckwheat flour proteins. Food Chem, 98, 90-94 